Working Paper \#004/2021

\title{
Contracting Out Public Transit Services: A Competitive Performance-Based Approach
}

\author{
João M. Pinto \\ Católica Porto Business School, Catholic University of Portugal \\ E-mail: jpinto@porto.ucp.pt \\ Mário Coutinho dos Santos \\ CICEE - Centro de Investigação em Ciências Económicas e Empresariais \\ E-mail: mcsantos@autonoma.pt \\ Pedro Verga Matos \\ Instituto Superior de Economia e Gestão, Universidade de Lisboa \\ E-mail: pvmatos@iseg.ulisboa.pt
}

\begin{abstract}
This paper develops a bonus / malus incentive model to contracting out public transit services, and provides evidence on performance measures of a light-rail transit system operation, procured with a contract designed based on our modeling approach. Empirical results document that the implementation of a performance-based contract with an embedded incentive bonus / malus mechanism, may contribute to promote ridership patronage, increase the average ride, and ultimately significantly improving the overall economic operating efficiency of the system, measured by a 40 percent increase in the operating costs coverage ratio during the contract term.
\end{abstract}

\section{Keywords:}

public transportation; privatization; performance-based contracting; bonus / malus mechanism.

\section{JEL Codes:}

H40; L24; L33

DOI: https://doi.org/10.26619/UAL-CICEE/WPO4.2021

\footnotetext{
* Authors gratefully acknowledge Ricardo Fonseca's, former Metro do Porto's (MdP) Chairman and CEO, Mars 30 ${ }^{\text {th }}, 2011$ written consent to refer MdP's 2009 international tendering on this paper. We are also very thankful for insightful discussions with Alvaro Costa and Carlos Oliveira Cruz, and for the outstanding research assistance provided by Ana Madeira. All errors and omissions are our own responsibility. This research did not receive any specific grant from funding agencies in the public, commercial, or not-for-profit sectors.
} 


\section{Introduction}

More and more public transportation agencies and authorities around the world, are externalizing the provision of infrastructure development and the operation of their transit systems, raising a natural question: why are they doing this?

It is widely acknowledged that for decades, public transit agencies around the world have been striving for delivering good quality and socially fairly priced mobility services, while aiming at minimizing the environmental negative externalities associated, namely, with traffic congestion and safety, and air pollution (e.g., Xue et al., 2017; Pereira et al., 2017; Desaulniers and Hickman, 2007; Nash, 2005; Teal, 1985).

However, extant literature has documented that the provision of public transit services, more often than not, may have not, in general, achieved the economic, social and welfare goals underlying governmental contracting out for infrastructure development and operation.

It appears to be a well-established global trend, that financially strained and budgetarily constrained public transit service providers, have been facing increasing difficulties in investing on infrastructure and equipment, in improving operating efficiency, recovering ridership, and balancing the economics of the operation (e.g., National Academies of Sciences, Engineering, and Medicine, 2014).

Financial and budgetary constraints at the government level, may have also limited the governmental sponsorship of new transit infrastructure development projects and the revamping of the operation of existing ones.

The question of whether or not the ownership over economically productive assets, matters in terms of relative economic efficiency, has been a topic of extensive debate among academics, policymakers, regulators and practionners alike. A non-negligible body of the privatization literature, provide theoretical arguments and document empirical regularities, suggesting the dominance of the private over governmental management in terms of the relative economic efficiency of productive assets (e.g., Maksimovic and Phillips, 2001; Boycko et al., 1996; Vickers and Yarrow 1991; Yarrow 1986).

Such economic gains, arguably associated with the externalization of management activities to the private sector, are also predicted to be important drivers of the privatization 
of the operation of public transportation systems, through competitive performance-based contracting arrangements (e.g., Amaral, 2008; Rodrigues and Contreras-Montoya, 2005). ${ }^{1}$

During the last decades central and local governments alike, attempted to balance the economics of transit systems operation, striving for keeping transit fares low and the operation profitable, while reducing its operating costs, maintaining the level of service quality, and improving ridership (see, e.g., Xue et al., 2017; Teal, 1985).

However, the increase in households' disposable income and the rise on motorization rates, mass transit services experienced a steady decline in ridership over time. This environment, characterized by depressed demand, operating deficits, debt overhang, and even financial distress, carried non-negligible implications for regulated transit operators, namely, in terms of their ability to attract investment capital.

Nonetheless, as it is widely acknowledged, the operation of public transit systems in many metropolitan areas around the world, has been associated with technical and allocative inefficiency which, despite non-negligible governmental subsidization, put under significant distress the financial and budgetary condition of many transit system operators (see, e.g., Hudspeth and Wellman, 2018; Xue et al., 2017; Winston, 2000). ${ }^{2}$

Financial, budgetary constraints, and efficiency concerns, may have called the attention of public policymakers, to consider alternative procurement contracting arrangements for the development of infrastructure, and the delivery of public services. Namely, to procure the provision of infrastructure development, operation and financing of transit services from the private sector. These developments have promoted financial aid from state and local governments and fostered the level and amount of public mass transit competitive contracting, increasing the involvement of the private sector in the provision of public transit operation services (e.g., Buso et al., 2017; Percoco, 2014; Levin and Tadelis, 2010; Maskin and Tirole 2008; Annez, 2006; Transportation Research Board and National Research Council 2001).

\footnotetext{
${ }^{1}$ Hereafter, we use interchangeably 'competitive contracting', 'competitive tendering', 'performance-based contracting', 'competitive bidding' and 'incentive contracting'.

${ }^{2}$ According to the Transportation Research Board and National Research Council (2001, pp. 138), in the United States «a decline in the demand for transit services began in the 1920s, accelerating after World War II. Private operators, already unable to attract investment capital in a regulated environment with falling demand, found it increasingly difficult to cover operating costs. By the $1950 \mathrm{~s}$, hundreds of systems were failing or in severe financial distress».
} 
Since the 1970s and 1980s, a dynamic stream of innovative financial instruments and customized structuring designs, enlarged significantly the supply of corporate financing arrangements in various forms of asset-backed structured financing, namely, limited recourse project financing, public-private partnerships (PPPs, hereafter), asset securitization, and structured leasing (e.g., Pinto and Coutinho dos Santos, 2019; Armeni and De Bone, 2017; Allen and Yago, 2010; Frame and White, 2010, 2004; Fabozzi et al., 2006; Annez, 2006; Caselli and Gatti, 2005; Tufano 2003; Duffie and Rahi, 1995; Finnerty, 1988). ${ }^{3}$

Increasingly more and more mass transit agencies and authorities worldwide have been sponsoring the privatization of public transport systems operation through competitive contracting out (e.g., Nash, 2005). In Europe, transit privatization initiatives conducted under contracting out transit operation services, become more frequent in the early $1980 \mathrm{s.}^{4}$

However, there is a relatively scanty literature addressing the question of design contracting arrangements that might promote the alignment of the objective's functions and incentives of the various stakeholders involved in such deals. In this paper, we contribute to this literature, developing a incentive performance-based approach model to contracting out public transit services, and documenting of some performance measures from a contract designed based on our model.

The remaining of the study is organized as follows: Section 2 discusses the theoretical and empirical background. Next section describes our research design, methodological approach, and model specification. A final section, summarizes and offers concluding remarks.

\section{Theoretical and Empirical Background}

\section{The ownership of business activities}

Prior academic and practionners work on the economic consequences of the privatization of state-owned assets, document abundant and compelling evidence on economic, financial, and operating performance gains, following such ownership divestitures.

\footnotetext{
${ }^{3}$ For further details see, e.g., Pinto (2013) and references cited therein. Structured finance encompasses all financial arrangements helping to efficiently (re)finance a specified pool of assets beyond the scope of on-balance sheet financing. Thus, the presence of a separate vehicle company (SPV or SPE) from the party or parties sponsoring the transaction is a key feature of such transactions.

${ }^{4}$ For more details, please refer to Transportation Research Board and National Research Council (2001, pp. 138147).
} 
Therefore, if the operation of governmentally owned assets is more efficient under private management, it can be expected that the performance improvements associated with privatization arrangements, would yield allocative and productive efficiency gains.

Extant privatization literature, provides abundant evidence consistent with the hypothesis that the privatization of business activities, generates performance improvements that translate into significant gains, namely, in terms of profitability, operating efficiency, investment and production (e.g., Megginson 2004; Wei et al., 2003; Sheshinski and LópezCalva, 2003; Dewenter and Malatesta 2001; Megginson and Netter 2001; Shirley and Walsh, 2000; D'Souza and Megginson 1999; Boubakri and Cosset 1998; Megginson, Nash and Van Randenborgh 1994).

Extant literature is consistent with the argument that performance-based competitive contracting of public transit system operation may be instrumental «to combine the efforts of public and private institutions related to public transport for the purpose of coordinating services, networks, and fares so as to offer consumers a higher-capacity, higher-quality service, with the aim of promoting public transport use and shifting demand away from private cars» (García-Ferrer et al. 2006). In the same vein, Hencher and Houghton (2004) argue that in many countries, there are growing concerns with operating cost efficiencies of bus transit operation services associated with «mixtures of privatisation, economic deregulation and competitive tendering and finding ways to grow patronage». ${ }^{5}$

The economic gains potentially associated with the privatization of management, are also suggested as a determinant factor in the strong and growing tendency to privatize the operation of public transit systems through the use of sub-concession public offer mechanisms (e.g., Amaral 2008; Rodrigues and Contreras-Montoya 2005). For example, Nash's (2005) examination of privatization phenomena in the transportation sector, concludes that «for rail and bus services, franchising of passenger services and outright privatization of freight appear to have achieved both efficiency improvements and improved services».

It is well-acknowledged that state sponsorship of public goods provision may have been constrained by budgetary and financial restrictions at the government level, and by concerns over the allocative efficiency of public resources. To address these policymaking constraints, public-private partnerships (PPPs) contracting, start being extensively used by

\footnotetext{
${ }^{5}$ See Sarmento and Renneboog (2016) for an analysis of different procurement systems.
} 
public administration bodies to procure design-build-finance-operate (DBFO) services, aiming at mitigating and reaping the performance improvements associated with the private delivery of public goods (e.g., Reagan et al. 2011; Levin and Tadelis 2010). Under these conditions, there was a significant increase in the volume of infrastructure projects funded in structured finance worldwide markets, in the form of either non-recourse project finance (PF, hereafter), public-private partnership (PPP, hereafter), or structured leasing transactions. ${ }^{6}$

According, e.g., to Kwak et al. (2009), well designed and managed PPPs «can provide a number of benefits to the public sector such as: alleviating the financial burden on the public sector due to rising infrastructure development costs; allowing risks to be transferred from the public to the private sector; and increasing the "value for money" spent for infrastructure services by providing more efficient, lower cost, and reliable services». These PPPs' attributes granted them widespread notoriety, to a large extent, built on their potential advantages, namely in terms «...alleviating the financial burden on the public sector», and in providing «efficiency incentives from private sector management into network industries» (ITF 2017; Kwak et al., 2009). ${ }^{7}$ However, efficiency gains of DBFOs arrangements associated with bundling construction and operations services in a single contract may, as argued by Maskin and Tirole (2008), be elusive because «the best developer might not also be the best operator». Further, it may encourage choices that reduce future costs at the expense of service quality» (see also Hart, 2003).

Albalate et al. (2010) analyze, in a public-private partnership framework, the challenges and opportunities of partial privatization of the public bus service provision in the metropolitan area of Barcelona, arguing that sub-concessions to private operators may "stimulate improved performance among public managers".

In another perspective, Sarmento and Renneboog (2016) point out that the incomplete nature of the contracts in PPPs make them prone to be renegotiated, and that renegotiation outcomes tend to rely on the position of the government.

\footnotetext{
${ }^{6}$ In a typical PPP, the governmental party contracts with a private partner the development, the construction, the financing and the operation of a project, being compensated by some "combination of government payments and user fees" (Maskin and Tirole 2008). According to Pinto and Pacheco (2014), structured leases, typically used to fund large assets, are versatile instruments that enable the lessee to position the deal in an optimal manner in relation to cash flow structure, its sustainability over time and the distribution of tax benefits.

${ }^{7}$ As posited in Maskin and Tirole (2008, pp. 413) «the marked increase in PPP contracts worldwide is often attributed less to the intrinsic qualities of such contracts than to governments' attempts to evade budget constraints by taking liabilities off the balance sheet». See also Vaslavskiy and Vaslavskaya (2019).
} 
Findings on the operating performance of Spanish bus companies indicate that «public firms are more intensive in the use of labor, but workers' productivity is lower compared to those in private firms. However, wages are 18 per cent higher in public firms. These facts indicate the presence of allocative X-inefficiency in public firms, which is observed in the different performance of both groups: average costs are 42 per cent higher in public than in private firms» (De Rus \& Nombela 1997).

According to Sheshinski and López-Calva (2003), theoretically «it is known that incentive and contracting problems create inefficiencies due to public ownership». One of them is the equitability of the reward systems stipulated in performance-based contracting arrangements. Such provisions should not be sensitive, either positively or negatively, to factors exogenous to the transit operator's contractual activity. For example, changes in regulated transportation fares, either inducing the increase or the decrease in ridership, should not be reflected on the contractual performance measures of the Sub-Concessionaire (e.g., Hensher and Stanley, 2003).

Sarriera et al. (2018) examines the impact of (lack of) productivity growth, union bargaining power, and contracting out on cost escalation, based on a sample of 415-bus U.S. transit agency for the1997-2014 period. Authors find that, in recent decades, unit costs per vehicle mile of bus operators have increased considerably above the inflation rate in recent decades.

\section{Transit Services Contracting Out}

A non-negligible number of public transit agencies across the world, experienced significant cost increases, economic deficits, and liquidity shortfalls during the last decades. Further, whenever promoting the efficiency of public transit services delivery is a major public policymaking objective, performance-based procurement, e.g., in the form of competitive tendering, should be a serious contender to be considered (e.g., Hensher and Wallis, 2005).

A panel data analysis conducted by Roy and Yvrande-Billon (2007) to a sample of 135 different French urban transport networks over the period 1995-2002, documents that the technical efficiency of public mass transit provision, may be affected by car ownership and the passenger-based incentives included in the contract design. In the U.S., according to Love and Cox (1993), «transit operating costs per vehicle mile increased 418 percent from 1970 to 
1990 twice the rate of inflation and two-and-a-half times the cost of similar service in the private bus industry».

In this framework, mass transit public agencies may have been led to switch from directly operating their transit networks to contracting out their service operations with private operators (e.g., Teal 1991; Reich and Davis, 2011; Nicosia, 2001). ${ }^{8}$

Competitive contracting has drawn significant attention in, among others, academic, policymaking, regulatory, and industry communities. It is relatively consensual among those communities, that the competitive delivery of «good quality, integrated and continually improving transit service that is available to all for a fair price, with return to operators that gives value for money under a regime of continuity», is a major objective in procuring the provision of public transit services (Hensher and Stanley, 2008).

According to this literature, performance-based contracting of public transit services, namely through competitive tendering, appears to be an appropriate vehicle «to combine the efforts of public and private institutions related to public transport for the purpose of coordinating services, networks, and fares so as to offer consumers at higher-capacity, higherquality service, with the aim of promoting public transport use and shifting demand away from private cars» (García-Ferrer et al., 2006). ${ }^{9}$

Because in numerous public transit systems fares are governmentally regulated, and concessionaires have contractual property rights over farebox collection, under a public mass transit gross-cost contract, sub-concessionaires albeit they don't incentives to ensure farebox revenue collection, the contract may require him to fulfill some stewardship duties, such as fare collection monitoring and fare evasion control.

According to Weitzman (1980), an incentive contract is «a linear payment schedule where the buyer pays a fixed fee plus some proportion of project cost». This theoretical approach to efficient contracting, based on a tradeoff between risk-sharing and incentives, may be suitable for practical implementation.

\footnotetext{
${ }^{8}$ As suggested by Reich and Davis (2011), a «method that has long been credited with increasing transit efficiency and reducing operating costs is contracting with the private sector for the provision of transit service». Additionally, Maurya (2018) posits that «dissatisfaction with the government delivery of services and search for a low-cost, high-quality alternative drove the movement for privatization and contracting out».

${ }^{9}$ According to Hensher and Stanley (2008), performance-based contracting «combines payment for delivering a minimum level of service (...) plus an incentive that rewards operators for patronage increases» above the minimum level of service in terms of both service and patronage.
} 
Transit service contracts may include monetary incentives based upon a specific performance metric, to incentivize contractors to outperform services beyond the goals contractually stipulated. Similarly, contracts may also involve monetary penalties to be enforced whenever non-compliance with contractual service goals verifies (e.g., Hillman and Feigenbaum, 2020; Vigren and Pyddoke, 2020).

Performance-based contracts typically include monetary penalties to be enforced whenever contractual service goals, such as, ridership, service standards in terms, e.g., quality and frequency, and level of customer satisfaction, are not met, a malus (e.g., Hillman and Feigenbaum, 2020).

There is a broad agreement among academics, policymakers, regulators and practionners, that performance-based competitive contracting of «good quality, integrated and continually improving transit service that is available to all for a fair price, with return to operators that gives value for money under a regime of continuity», is a key goal in contracting public transit services (Hensher and Stanley, 2008).

In this framework, the rationale for stipulating Sub Concessionaire's contractual incentives, should reflect Concessionaire's expectations on cost efficiency gains, operating improvements and patronage increases.

Prior work suggests that performance-based contracting of transit service provision is consistent, under specific budgetary, regulatory and geographical conditions, with the principle of social surplus maximization. However, competitive tendering may be less effective (e.g., Hensher and Stanley, 2008).

Among the more ubiquitous contractual arrangements in transit services competitive tendering are the cost-plus contract, the gross cost contract, and the gross cost contract with incentives. In a cost-plus contract, sub-concessionaire is compensated for all the contractually stipulated expenses, plus additional payment to allow for a profit. The more conspicuous features in a cost-plus contracting model, include: $(i)$ the assignment of farebox revenue property rights to the concessionaire; (ii) the sub-concessionaire is reimbursed for operating costs, which may include a management fee; (iii) no risk-sharing, either commercial or 
operational; and (iv) the only incentive for costs control is the risk of non-renewal of the contract. $^{10}$

A gross cost type of contract is awarded to the lowest gross cost bidder. Property rights of farebox revenue are assigned to the concessionaire. The sub-concessionaire is compensated with a specified monetary sum, submitted to competition, for providing the specified operation services stipulated in the contract, which typically also includes penalties for non-compliance. The sub-concessionaire is not exposed to commercial risk, but it is to operational risk.

In a 'gross cost with incentives' contracting arrangement, the farebox revenue is property of the concessionaire. The sub concessionaire is remunerated based on a demandbased criterion, for example ridership measured in passenger-kilometer, which is submitted to competition. It constitutes an incentive for a sub-concessionaire to increase its remuneration, promoting actions to foster demand. In this contracting model, the sub-concessionaire is exposed to operational risk, and partly to demand risk, through an incentive mechanism, such as, a bonus / malus mechanism, which constitutes an incentive for the sub-concessionaire to engage in actions to promote ridership and increase his monetary compensation. ${ }^{11}$

\section{Research Design, Methodological Considerations and Model Specification}

The set of assumptions underlying the specification of our 'gross cost with incentives' contracting model include: a 5 to 10 years contract term; transit fares set at the regulatory level; farebox collection under the Concessionaire; and Concessionaire's estimation of transit demand function.

Transit demand functions have been estimated under different econometric specifications. Our modeling setup, in methodologically anchored in log-log regression econometric approach to estimate a transit demand function, the 'forecasted demand', estimation.

Several methodological arguments endorse the use of isoelastic demand functions for estimating ridership of public transit systems. A first argument, favoring the use of this nonlinear regression specification, is anchored in the particularly interesting feature, of the

\footnotetext{
${ }^{10}$ Cost-reimbursement contracts contrast with fixed-price contract, in which contractors are paid a negotiated monetary amount regardless of the expenses incurred in the provision of the object of the contract.

${ }^{11}$ Is exposed to only the quantity component of the commercial risk because, besides transit fares being governmentally regulated, farebox revenue is collected by the concessionaire.
} 
explanatory variable's coefficient estimators measuring the constant partial elasticities to the dependent variable (see, e.g., Gujarati and Porter, 2009; Allen et al., 2005; Weber and Hawkins, 1971). ${ }^{12}$

García-Ferrer et al. (2006), estimated the elasticity of demand for public passenger transport in the transport system of the Metropolitan Area of Madrid, adopt a different model due to using use demand monthly data, which exhibit significant levels of non-stationary seasonality.

A second argument builds on the 'reasonableness' of the assumption of constant partial elasticities. There is abundant empirical evidence supporting the hypothesis that the elasticity of demand for public transit systems is constant in relation to its explanatory variables over the short / medium-term time horizons. Nijkamp \& Pepping (1998) argue that the likelihood of such demand elasticity reflecting changes in the conditions of provision of the transport service, is higher for longer time horizons. Therefore, authors conclude that it is expected, that long-term elasticities to be higher than short-term. This conclusion can be interpreted as providing support for the argument that elasticity of demand for public transit systems to be stationary over medium-term time horizons (5 to 10 years). ${ }^{13}$ According to Hensher and Young (1991), the Research Transport Center of the Bureau of Transport and Communications Economics, Canberra, Australia, recommends a five-year fuel price elasticity in the road passenger vehicle segment (see also, e.g., Graham and Glaister, 2002; Goodwin, 1992; Hensher and Young, 1991). Oum et al. (1992) state that there is strong empirical evidence showing that the demand for individual and collective (urban) passenger transport is inelastic.

In the same sense, Nijkamp \& Pepping (1998) analyze «(..) own-price regular elasticities, where the dependent variable is travel volume, and the independent variable is travel cost».

\footnotetext{
${ }^{12}$ See García-Ferrer et al. (2006) for an estimation of demand elasticity for the multi-modal transit system of the Metropolitan Area of Madrid. Their regression specification is particularly relevant in the context of an intermodal public transit system, because it documents that the hypothesis that modal demand-price crosselasticity may be stationary, cannot be rejected.

${ }^{13}$ Is worth noting that the contractual term, may also be related to demand elasticity. Under a bonus / malus incentive contract, the mechanisms a sub concessionaire may adopt to increase in patronage to maximize bonus, requires a minimum period of time for producing output effects and for internalizing the associated costs.
} 
The specification of a regression model should be adequately grounded on the relevant theoretical and empirical literature. Explanatory variables most frequently used in econometric models for estimating transit demand include, among others, disposable income, fuel prices, prices of other transport modes, and variables associated with demography, such as the resident population and the rate of activity.

The specification of our Bonus / Malus contracting model, is based under a set of assumptions that the concessionaire, either directly or through outsourcing with professional consultancy, including: (i) Developed a standard costing estimation on both fixed and variable costs of the transit system operation, to ensure that the Sub Concessionaire compensation is based on efficient costing benchmarks. Those cost benchmarks, should allow estimating 'vehicle_Km' standard cost, decomposed into 'vehicle_Km fixed standard cost' $\left(k_{F}\right)$, and 'vehicle_Km variable standard cost' $(k v)$, main elements of the Sub Concessionaire's remuneration contractual arrangement; (ii) constructed a long-range (20 to 30 years) demand forecast for the same time horizon of the system's masterplan, under previously validated methodology and assumptions; (iii) developed a mandatory minimum system operation schedule (MOS) for the transit network on its current configuration, based on the 'forecasted demand' for the term of the contract; (iv) stipulated the profit margin, $m$, allowed to the operator; and (v) defined the upper (UL) and lower limits (LL) of the demand band. ${ }^{14}$

The forecasted demand is specified as an isoelastic demand function: ${ }^{15}$

$$
Y=b X^{a} Z^{c}
$$

where $Y$ denotes forecasted demand, $X$ denotes the ratio of the individual average monthly out of the pocket expenses of individual travel (ITC), including fuel, parking, and freeway tolls, to the average monthly out of the pocket expenses of public transportation (PTC), the average cost of a non-subsidized monthly season ticket, and $Z$ is an activity rate variable, specified as the relationship between the active population and the population aged 16 and over. ${ }^{16}$

\footnotetext{
${ }^{14}$ Because the MOS mandatory operation service requirements is not subject to competition, it involves penalties for contractual noncompliance.

${ }^{15}$ See Appendix A for the derivation of estimators of the forecasted demand function coefficients.

${ }^{16}$ The inclusion of the ITC / PTC ratio as explanatory variable is made under the assumption, that both the numerator and denominator, vary inelastically to transit demand.
} 
The subconcessionaire's compensation scheme has three components. A first component covering operator's fixed costs incurred in fulfilling its contracting obligations $\left(R_{F}\right)$ to be computed as:

$$
R_{F}=\left[\left(k_{F}\right)(1+m)\right] V_{k m}
$$

where $k_{F}$ denotes 'vehicle_Km fixed cost', $m$ denotes a percentage profit margin allowance, and $V_{k m}$ denotes the annualized 'vehicle $\mathrm{x}$ Km' production during the time horizon of the contract. The expression $\left[\left(k_{F}\right)(1+m)\right]$, quantifies the 'profit adjusted vehicle $\mathrm{x}$ Km fixed cost', to be submitted to competitive bidding. The second compensation component $\left(R_{V}\right)$ covers operator's variable costs and is to be computed as:

$$
R_{V}=\left[\left(k_{V}\right)(1+m)\right] V_{k m}
$$

where $k_{v}$ denotes the 'vehicle $\mathrm{x} \mathrm{Km}$ variable cost'. The expression $\left[\left(k_{v}\right) \mathrm{x}(1+M)\right]$, which quantifies the 'profit adjusted vehicle $\mathrm{x} \mathrm{Km}$ variable cost', to be submitted to competitive bidding. ${ }^{17}$

The third component, a 'Bonus / Malus' (B/M) annual reward system, builds on equitability concerns. To be fair, a bonus / malus incentive scheme should be insensitive to changes in any factor out of the subconcessionaire's control. To that end, annual realized demand during the contractual term, must be annually adjusted for the variation in the partial constant elasticities implicit in the forecasted demand function.

It is a function of the relative performance of the 'adjusted realized demand' on period $t$, in relation to the 'forecasted demand' on the same period, both measured in 'Passenger $\mathrm{x}$ Km' $\left(\right.$ Pax $\left._{\mathrm{km}}\right)$, whenever the first is out of the 'demand band' (DB) defined by a lower (LL) and an upper (UL) percentual thresholds:

\footnotetext{
${ }^{17}$ Contractual provisions should enact the annual application of an escalation formula to both $k_{F}$ and $k_{V}$, to adjust for price level changes, and warrant that competitive market conditions are adequately enforced.
} 


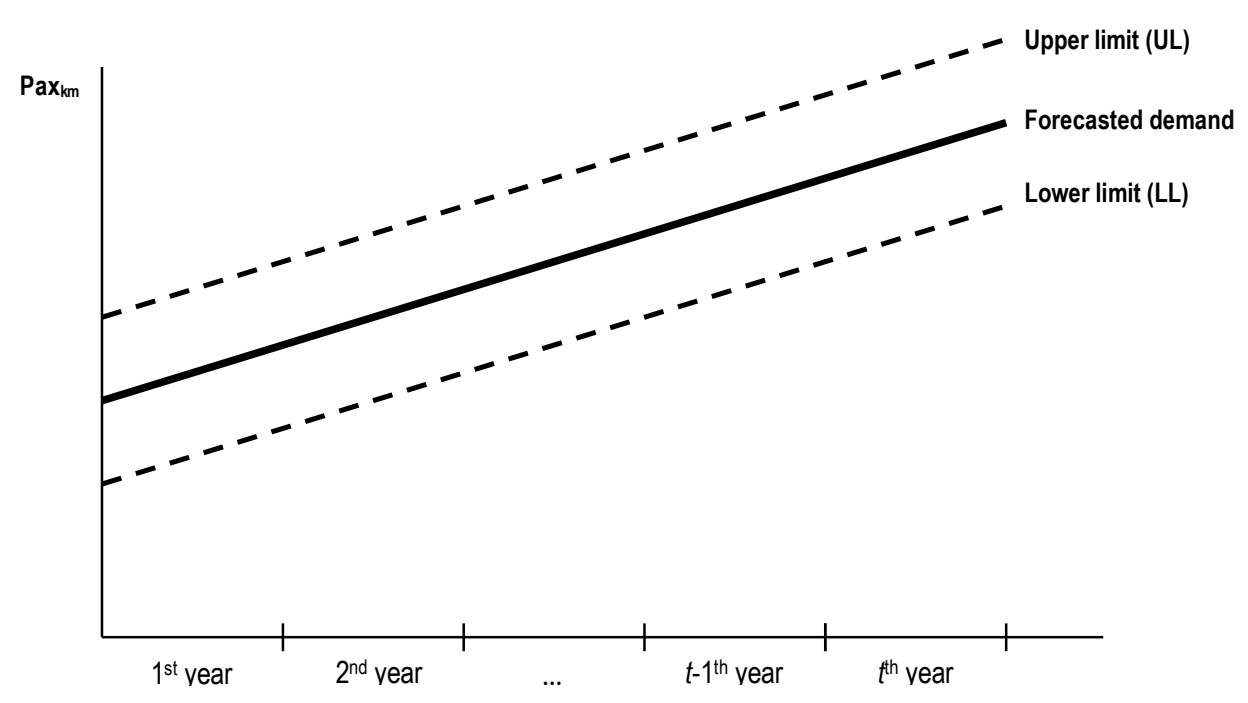

Whenever the annual adjusted realized demand falls within the 'Demand Band', the Bonus / Malus reward mechanism is inapplicable.

The annual $\mathrm{B} / \mathrm{M}$ value is computed using the following algorithm:

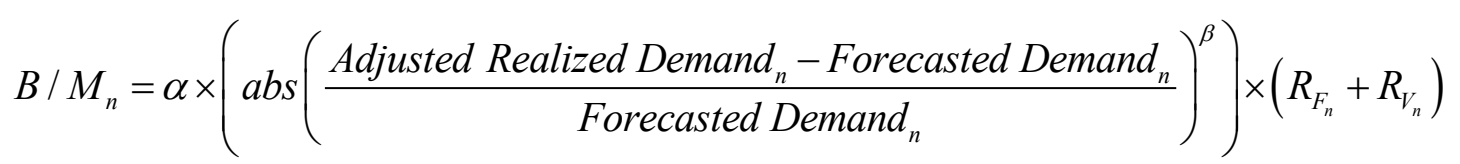

Parameters $\alpha$ and $\beta$ are defined by the concessionaire assuming a law of diminishing marginal returns. $^{18}$

The adjusted realized demand in year $n$ is computed as follows:

$$
\text { Adjusted Realized Demand }_{n}=\text { Realized Demand }_{n} \frac{\text { Elasticity }_{\text {Yto }_{n}}}{\text { Elasticity }_{b}} \frac{\text { Elasticity }_{\text {Ito }_{n}}}{\text { Elasticity }_{c}}
$$

The annual adjustment of realized demand accounts for the variations on the independent variable's constant elasticities implicit in the forecasted demand function, to annual elasticities computed as:

$$
E_{Y \text { to } X_{n}}=\frac{\log \left(\frac{\text { Adjusted Realized Demand }_{n}}{10^{6}}\right)-b}{\log X}
$$

where $E_{X, Y n}$ denotes variable $Y$ elasticity to $X$ in year $n$, and $b$ variable $Y$ implicit partial constant elasticity to $X$.

\footnotetext{
${ }^{18}$ The upper limit of the bonus mechanism is asymptotically limited by the maximum load factor implied by a maximum 4 per $\mathrm{m}^{2}$ passenger occupation, assumed as the lowest admissible passenger' s comfort level (e.g., Lomas 2009).
} 
and

$$
E_{Y \text { to } Z_{n}}=\frac{\log \left(\frac{\text { Adjusted Realized Demand }_{n}}{10^{6}}\right)-c}{\log Z}
$$

where $E_{Z, Y n}$ denotes variable $Y$ elasticity to $Z$ in year $n$, and $c$ variable $Y$ implicit partial constant elasticity to $Z$.

\section{Concluding Remarks}

Extant literature highlights the promotion of ridership, and operating cost efficiency gains, as major determinants of competitive contracting out of public transit systems.

In 2009 Metro do Porto (MdP) conducted an international tender offering to operate and maintain its light-rail system, based on publicly available information from MdP's website, (see Table 1, below)

Table 1 - Performance during the 2010-14 contract term

\begin{tabular}{|l|c|c|c|c|c|c|}
\cline { 2 - 7 } \multicolumn{1}{c|}{} & $\begin{array}{c}\text { Average } \\
2008-9^{*}\end{array}$ & 2010 & 2011 & 2012 & 2013 & 2014 \\
\hline Pax Km $\left(10^{3}\right)$ & 260,239 & 267,064 & 290,700 & 282,480 & 285,591 & 288,136 \\
\hline Farebox revenue $\left(10^{3}\right.$ euros) & 29,592 & 30,649 & 34,945 & 37,370 & 38,879 & 39,685 \\
\hline Revenue / Pax Km (euro cents) & 11.37 & 11.48 & 12.02 & 13.23 & 13.61 & 13.77 \\
\hline Operating costs $\left(10^{3}\right.$ euros) & 49,573 & 42,570 & 42,092 & 43,217 & 43,580 & 43,685 \\
\hline Operating costs / Pax Km (euro cents) & 19.05 & 15.94 & 14.48 & 15.30 & 15.26 & 15.16 \\
\hline Coverage ratio & $59.7 \%$ & $72.0 \%$ & $83.0 \%$ & $86.5 \%$ & $89.2 \%$ & $90.8 \%$ \\
\hline Average ride $(\mathrm{km})$ & 5.001 & 4.987 & 5.216 & 5.183 & 5.106 & 5.062 \\
\hline
\end{tabular}

Source: Primary data drawn from Metro do Porto's 2012 and 2014 annual reports, publicly available at: http://www.metrodoporto.pt/PageGen.aspx?WMCM PaginaId=17246).

* The 2008-2009 average refers to the two last years of MdP's light-rail operation services, performed under the previous (design-build-operate) bundled contractual arrangement.

In line with Nicosia (2001) that document significant cost-savings at $14 \%$ of operating costs attributable to contracting, in a sample over 300 U.S. transit firms, we found that in comparison with the average performance of the two pre-contract years, the data for the 20102014 contract term documents average improvements of: $(i) 8.7$ percent on the patronage measured in terms of passenger km, 2.2 percent on average ride length, and 22.7 percent on farebox revenues; (ii) a 20.1 percent reduction on operating cost per passenger $\mathrm{km}$, indicating that the contract efficiency; and (iii) a 40.2 percent increase on the coverage ratio of operating costs by farebox revenues.

The MdP light-rail case documents, in line with extant literature, that the implementation of a performance-based contract with an incentive bonus / malus mechanism, 
may contribute to promote ridership patronage, increase the average ride, and ultimately significantly improving the overall economic operating efficiency of the system, gauged by a 40 percent increase in the operating costs coverage ratio. 


\section{References}

Albalate, D., G. Bel \& J. Calzada. 2010. Urban Transport Governance Reform in Barcelona. Universitat de Barcelona Research Institute of Applied Economics working paper $n^{\circ}$ 2010/09.

Allen, F. \& G. Yago. 2010. Financing the Future Market-Based Innovations for Growth. Wharton School Publishing, Upper Saddle River (NJ), USA.

Allen, W., N. Doherty, K. Weigelt \& E. Mansfield. 2005. Managerial Economics: Theory, Applications and Cases, $6^{\text {th }}$ Ed. W. W. Norton, New York (NY), USA.

Amaral, M. 2008. Public vs Private Management of Public Utilities - The Case of Urban Public Transport in Europe. Research in Transportation Economics 22(1): 85-90.

Annez, P. 2006. Urban Infrastructure Finance from Private Operators: What Have We Learned from Recent Experience? World Bank Policy Research Working Paper No. 4045.

Armeni, A \& M. De Bone. 2017. Innovations in Financing Structures for Impact Enterprises: Spotlight on Latin America. Inter-American Development Bank. Washington, D.C., USA.

Boubakri, N. \& J.-C. Cosset 1998. The Financial and Operating Performance of Newly Privatized Firms: Evidence from Developing Countries. Journal of Finance 53(3): 1081-1110.

Boycko, M., A. Shleifer \& R. Vishny. 1996. A Theory of Privatization. Economic Journal 106(435): 309-319.

Buso, M., F. Marty \& P. Tran. 2017. Public-Private Partnerships from Budget Constraints: Looking for Debt Hiding? International Journal of Industrial Organization 51 (March): 56-84.

Caselli, S. \& S. Gatti. 2005. Structured Finance: Techniques, Products and Market. Springer, Berlin, Germany.

D'Souza, J. \& W. Megginson. 1999. The Financial and Operating Performance of Privatized Firms during the 1990s. Journal of Finance 54(4): 1397-1438.

De Rus, G. \& G. Nombela. 1997. Privatisation of Urban Bus Services in Spain. Journal of Transport Economics and Policy 31(1): 115-129.

Desaulniers, G. \& M. Hickman. 2007. Public Transit. In C. Barnhart \& G. Laporte, Editors. Handbook in OR \& MS, Vol. 14, Chapter 2: 69-127. Elsevier, Amsterdam, Netherlands.

Dewenter, K. \& P. Malatesta. 2001. State-Owned and Privately Owned Firms: An Empirical Analysis of Profitability, Leverage, and Labor Intensity. American Economic Review 91(1): 320-334.

Fabozzi, F., H. Davis \& M. Choudhry. 2006. Introduction to Structured Finance. John Wiley \& Sons, Hoboken (NJ), USA.

Frame, S. \& L. White. 2004. Empirical Studies of Financial Innovation: Lots of Talk, Little Action? Journal of Economic Literature 42(1): 116-144.

Frame, W. \& L. White. 2010. Technological Change, Financial Innovation, and Diffusion in Banking. In A. Berger P. Molyneux \& J. Wilson, Editors. 2010. The Oxford Handbook of Banking, Chapter 19: 486-507. Oxford University Press, New York (NY), USA.

García-Ferrer, A., M. Bujosa, A. de Juan \& P. Poncela. 2006. Demand Forecast and Elasticities Estimation of Public Transport. Journal of Transport Economics and Policy 40(Part 1): 45-67.

Goodwin, P. 1992. A Review of New Demand Elasticities with Special Reference to Short and Long Run Effects of Price Changes. Journal of Transport Economics and Policy 26(2): 155-169.

Graham, D. \& S. Glaister. 2002. The Demand for Automobile Fuel: A Survey of Elasticities. Journal of Transport Economics and Policy 36(1):1-25.

Gujarati, D \& D. Porter. 2009. Basic Econometrics, $5^{\text {th }}$ Ed. McGraw-Hill, New York (NY), USA. 
Hart, O. 2003. Incomplete Contracts and Public Ownership: Remarks, and an Application to Public Private Partnerships. The Economic Journal 113(485): C69-C76.

Hensher, D. \& E. Houghton. 2004. Performance-based Quality Contracts for the Bus Sector: Delivering Social and Commercial Value for Money. Transportation Research Part B 38: 123-146.

Hensher, D. \& I. Wallis. 2005. Competitive Tendering as a Contracting Mechanism for Subsidising Transport: The Bus Experience. Journal of Transport Economics and Policy, Volume 39, (Part 3): 295-321.

Hensher, D. \& J. Stanley. 2003. Performance-based Quality Contracts in Bus Service Provision. Transportation Research Part A 37(6): 519-538.

Hensher, D. \& J. Stanley. 2008. Transacting under a Performance-based Contract: The Role of Negotiation and Competitive Tendering. Transportation Research Part A 42: 1143-1151.

Hensher, D. \& J. Young. 1991. Demand Forecasts and Demand EIasticities for Australian Transport Fuel. Bureau of Transport and Communications Economics Occasional Paper 103, Transport Research Centre, Macquarie University, Canberra, Australia.

Hensher, D. 2006. Delivering Value for Money to Government through Efficient and Effective Public Transit Service Continuity: Some Thoughts. Working Paper WP-06-19, Institute of Transport and Logistics Studies, University of Sydney, Australia.

Houghton, E. \& D. Hensher. 2005. Negotiated and Competitively Tendered Performance-Based Contracts. D. Hensher K. Button Editors Handbook of Transport Strategy, Policy and Institutions Vol. 6: 527-546. Elsevier, Amsterdam, Netherlands.

Hudspeth, N. \& G. Wellman. 2018. Equity and Public Finance Issues in The State Subsidy of Public Transit. Journal of Public Budgeting, Accounting \& Financial Management 30(2): 135-155.

ITF. 2017. Public Private Partnerships for Transport Infrastructure: Renegotiation and Economic Outcomes. ITF Roundtable Reports, OECD Publishing, Paris, France.

Kwak, Y., Y. Chih \& C. Ibbs. 2009. Towards a Comprehensive Understanding of Public Private Partnerships for Infrastructure Development. California Management Review 51(2): 51-78.

Levin, J. \& S. Tadelis. 2010. Contracting for Government Services: Theory and Evidence from U.S. Cities. Journal of Industrial Economics 58(3): 507-541

Lomas, B. 2009. Topic Sheet No. 5 - A Question of Capacity. TramForward, Herts, UK.

Maksimovic, V. \& G. Phillips. 2001. The Market for Corporate Assets: Who Engages in Mergers and Asset Sales and Are There Efficiency Gains? Journal of Finance 56(6): 2019-2065.

Maskin, E. \& J. Tirole. 2008. Public-Private Partnerships and Government Spending Limits. International Journal of Industrial Organization 26(2): 412-420.

Megginson, W. \& J. Netter. 2001. From State to Market: A Survey of Empirical Studies on Privatization. Journal of Economic Literature 39(2): 321-389.

Megginson, W. 2004. The Financial Economics of Privatization. Oxford University Press, New York (NY), USA.

Megginson, W., R. Nash \& M. Van Randenborgh. 1994. The Financial and Operating Performance of Newly Privatized Firms: An International Empirical Analysis. Journal of Finance 49(2): 403-452.

Nash, C. 2005. Privatization in Transport. In K. Button \& D. Hensher, editors, Handbook of Transport Strategy, Policy and Institutions, Volume 6: 97-112. Elsevier, Amsterdam, Netherlands.

National Academies of Sciences, Engineering, and Medicine 2014. Maintaining Transit Effectiveness Under Major Financial Constraints. The National Academies Press, Washington (DC), USA. DOI: https://doi.org/10.17226/22340. 
Nicosia, N. 2001. Competitive Contracting in the Mass Transit Industry: Causes and Consequences. Working paper Department of Economics, University of California, Berkeley.

Nijkamp, P. \& G. Pepping. 1998. Meta-Analysis for Explaining the Variance in Public Transport Demand Elasticities in Europe. Journal of Transportation and Statistics January: 1-14.

Oum, T., W. Waters \& J. Yong. 1992. Concepts of Price Elasticities of Transport Demand and Recent Empirical Estimates: An Interpretative Survey. Journal of Transport Economics and Policy 26(2): 139-154.

Percoco, M. 2014. Quality of Institutions and Private Participation in Transport Infrastructure Investment: Evidence from Developing Countries. Transportation Research Part A 70: 50-58.

Pereira, R., T. Schwanen \& D. Banister. 2017. Distributive Justice and Equity in Transportation. Transport Reviews 37(2): 170-191.

Pinto, J. 2013. A Theoretical and Empirical Analysis of Structured Finance. Unpublished Doctoral dissertation, School of Economics and Management of the University of Porto.

Pinto, J. M. \& M. C. dos Santos. 2020. The Choice between Corporate and Structured Financing: Evidence from New Corporate Borrowings. The European Journal of Finance 26(13): 1271-1300.

Regan, M., J. Smith \& P. Love. 2011. Infrastructure Procurement: Learning from Private-Public Partnership Experiences 'Down Under'. Environment and Planning C: Government and Policy 29: 363-378.

Rodrigues, C. \& C. Contreras-Montoya. 2005.The Privatization Process of The Subway and the Suburban Train Systems in Rio de Janeiro: Contractual and Integration Aspects. Paper presented at the $9^{\text {th }}$ Conference on Competition and Ownership in Land Transport, Lisbon, Portugal.

Sarmento, J. \& L. Renneboog. 2016. Anatomy of Public-Private Partnerships: Their Creation, Financing and Renegotiations. International Journal of Managing Projects in Business 9(1): 94122.

Sarriera, J., F. Salvucci \& J. Zhao. 2018. Worse than Baumol's Disease: The Implications of Labor Productivity, Contracting Out, and Unionization on Transit Operation Costs. Transport Policy 61: 10-16.

Sheshinski, E. \& L. López-Calva. 2003. Privatization and its Benefits: Theory and Evidence. CESifo Economic Studies 49(3): 429-459.

Shirley, M. \& P. Walsh. 2000. Public versus Private Ownership: The Current State of the Debate. World Bank Policy Research Working Paper \# 2420.

Teal, R. 1985. Transit Service Contracting Experiences and Issues. Transportation Research Record 1036: 28-36.

Transportation Research Board and National Research Council. 2001. Contracting for Bus and Demand-Responsive Transit Services: A Survey of U.S. Practice and Experience, Special Report 258. The National Academies Press, Washington, DC, USA.

Tufano, P. 2003. Financial Innovation. In G. Constantinides, M. Harris \& R. Stulz, Editors. Handbook of the Economics of Finance, Vol. 1A, Chapter 6: 307-336. Elsevier, Amsterdam, Netherlands.

Vaslavskiy, Y. \& I. Vaslavskaya. 2019. Infrastructure Public-Private Partnership Projects: Budget Consolidation Policy in Russia and Government Expenditures' Efficiency Increase. In B. Sergi, Editor. Modeling Economic Growth in Contemporary Russia, Chapter 7: 203-231. Emerald Publishing, Bingley, UK.

Vickers, J. \& G. Yarrow. 1991. Economic Perspectives on Privatization. Journal of Economic Perspectives 5(2): 111-132. 
Weber, J. \& C. Hawkins. 1971. The Estimation of Constant Elasticities. Southern Economic Journal 38(2): 185-192.

Wei, Z., O. Varela, J. D’ Souza, \& M. Hassan. 2003. The Financial and Operating Performance of China's Newly Privatized Firms. Financial Management 32(2): 107-126.

Winston, C. 2000. Government Failure in Urban Transportation. Fiscal Studies 21(4): 403-425.

Xue, Y., H. Guan, J. Corey, H. Wei \& H. Yan. 2017. Quantifying a Financially Sustainable Strategy of Public Transport: Private Capital Investment Considering Passenger Value. Sustainability 9(269): 1-20.

Yarrow, G. 1986. Privatization in Theory and Practice. Economic Policy 1(2): 323-377. 
Appendix A | Estimators of an isoelastic demand function

The isoelastic demand function to be econometrically estimated under the standard ordinary least squares is specified as:

$$
Y=a X^{b} Z^{c} \varepsilon
$$

where $Y$ denotes the forecasted demand; $X$ and $Z$ the independent variables, such as the ratio of the average individual cost of private transportation to the average individual cost of public transportation, and the activity rate, $a$ is the regression equation independent term; $b$ is the constant elasticity of $X$ on $Y$; $c$ is the constant elasticity of $X$ on $Y$; and $\varepsilon$ is a random error term with zero mean and constant variance. ${ }^{19}$

The logarithmic transformation of (1) yields:

$$
\log Y=\log a+b \log X+c \log Z+\varepsilon
$$

Estimator of the independent term $a$ :

$$
a=\operatorname{anti} \log \left(\frac{\sum_{i=1}^{n} \log Y_{i}-a \sum_{i=1}^{n} \log X_{i}-c \sum_{i=1}^{n} \log Z_{i}}{n}\right)
$$

Estimator of the coefficient $b$ :

$$
b=\frac{\sum_{i=1}^{n} \log Y_{i} \log Z_{i}-\log b \sum_{i=1}^{n} \log Z_{i}-c \sum_{i=1}^{n}\left(\log Z_{i}\right)^{2}}{\sum_{i=1}^{n} \log X_{i} \log Z_{i}}
$$

Estimator of the coefficient $c$ :

$$
c=\frac{-\sum_{i=1}^{n} \log Y_{i} \log X_{i}+\log b \sum_{i=1}^{n} \log X_{i}+a \sum_{i=1}^{n}\left(\log X_{i}\right)^{2}}{\sum_{i=1}^{n} \log X_{i} \log Z_{i}}
$$

\footnotetext{
${ }^{19}$ In our empirical specification, variable $X$ represents the ratio of the individual average monthly out of the pocket expenses of private transportation (including fuel, parking, and freeway tolls) to the average monthly out of the pocket expenses of public transportation (average cost of a non-subsidized monthly season ticket), and variable $Z$ an activity rate (relationship between the population aged 16 and over to the active population).
} 